\title{
Pelatihan Dasar Kepemimpinan Taman Belajar Kreatif Mekarsari Kabupaten Bogor Jawa Barat
}

\author{
I Nyoman Marayasa ${ }^{1 *}$, Kharisma Danang Yuangga ${ }^{2}$, Udin Ahidin $^{3}$, Endang Sugiarti ${ }^{4}$, \\ Putri Nilam Kencana ${ }^{5}$ \\ 1,2,3,4,5 Program Studi Manajemen, Fakultas Ekonomi, Universitas Pamulang \\ Jl. Surya Kencana No.1, Pamulang Barat, Kec. Pamulang \\ Kota Tangerang Selatan, Banten 15417 \\ *Penulis Korespodensi: dosen00569@unpam.ac.id
}

\begin{abstract}
ABSTRAK
Tujuan diselenggarakannya kegiatan Pengabdian Kepada Masyarakat ini adalah untuk menumbuhkan jiwa kepemimpinan pada para Pengurus Taman Belajar Kreatif Mekarsari yang sesuai dengan perkembangan jaman yang aktual dan terkini. Selain itu dapat menggerakkan para anggota Pengurus untuk dapat mengembangkan jiwa kepemimpinan di era milenial seperti saat ini.Metode pelaksanaan dengan metode penyuluhan dan seminar. Hasil kegiatan setelah selesai LDK akan mampu mencari solusi dengan cara berpikir berbeda dari teman-teman lainnya. Hal itu akan menjadikan memiliki pola pikir jauh ke depan dan bisa mengantisipasi permasalahan
\end{abstract}

Kata Kunci :Kepemimpinan

\begin{abstract}
The purpose of this Community Service activity is to foster leadership in the Mekarsari Creative Learning Park Management in accordance with the current and current development. In addition it can move the members of the Board to be able to develop a leadership spirit in the millennial era as it is today. The method of implementation is with counseling and seminar methods. The results of activities after completion of the basic Leadership Training will be able to find solutions by thinking differently from other friends. That will make you have a long-term mindset and can anticipate problems
\end{abstract}

Keywords: Leadership

\section{PENDAHULUAN}

Kepemimpinan dalam organisasi adalah sebuah proses dimana seorang pemimpin memengaruhi dan memberikan contoh kepada pengikutnya dalam upaya mencapai tujuan organisasi (Sri Wiranti, 2009). Pemimpin yang baik bukan dilihat dari seberapa banyak orang yang menjadi pengikutnya, bukan juga dilihat dari seberapa lama ia memimpin (Badu \& Djafri, 2017). Pemimpin yang baik dilihat dari seberapa banyak ia mampu menciptakan sosok pemimpin yang baru (Sutikno, 2014). 
I Nyoman Marayasa, dkk

Kepemimpinan menjadi salah satu faktor penting bagi keberhasilan sebuah organisasi (Tampi, 2014). Untuk itu, ada beberapa sikap kepemimpinan dalam organisasi yang perlu diterapkan oleh seorang pemimpin (Siagian, 2003).

Identifikasi masalah yang ditemukan di lapangan adalah masih kurangnya pemahaman dan pengetahuan para remaja khususnya (Samarenna \& Siahaan, 2019) . Pengurus dalam hal mengatur diri dan membuat perencanaan kerja serta mengarahkan diri dalam membuat keputusan. Hal itu dikarenakan para anggota mayoritas masih belum memiliki pemahaman dan sikap dalam berorganisasi yang baik. Sehingga diperlukan Pelatihan Dasar Kepemimpinan untuk membentuk sikap dan mental mereka dalam berorganisasi.

Materi yang dibutuhkan akan disampaikan oleh para pemateri berkaitan dengan kepemimpinan berupa penyuluhan mengenai karakter pemimpin yang benar, ketrampilan menyusun rencana kerja dan pengambilan keputusan (Edy Kumara \& Utama, 2016) . Dilanjutkan dengan sesi komunikasi yang meliputi penyuluhan mengenai cara-cara berkomunikasi yang benar sebagai layaknya seorang pemimpin. Selain itu, ada juga sesi problem solving yaitu mengenai cara-cara seorang pemimpin memecahkan masalah secara efektif dan benar. Ada pula sebuah dinamika kelompok yang disajikan dalam permainan. Dan kegiatan ditutup dengan pembagian sertifikat oleh panitia kepada peserta Latihan Dasar Kepemimpinan.

Pelatihan LDK ini sangatlah penting dalam menjadikan genarasi muda yang tangguh dan membentuk jiwa pemimpin yang profesional. Manajemen kepemimpinan akan membentuk kader-kader pemimpin bangsa kecepannya. Segala ilmu yangg diperoleh dalam kegiatan ini tidak akan didapatkan di bangku kuliah. Segala pemikiran, sikap, dan integritas harus dimiliki pemimpin bangsa dalam mencapai cita-citanya. Dalam memimpin bangsa, mahasiswa sebagai kader penerus bangsa memiliki beban berat sebagai penerus bangsa di era globalisasi ini.

Masalah lain dalam Pengurus Taman Belajar Kreatif Mekarsari adanya anggot yang merasa dirinya kurang percaya diri dalam kehidupan sehari-hari, ada baiknya mengikuti LDK. Sebab, pada rangkaian pelatihan LDK, mereka akan dilatih untuk lebih percaya diri. Karena, berbagai materi yang akan diajarkan kepada kamu membantu kamu untuk mencari kelebihan diri kamu.

Selain itu, keharusan kamu aktif selama materi LDK disampaikan akan membantu untuk menghadapi rasa takut gagal yang menghantui pikiran. Biasanya, oleh fasilitator LDK, akan diminta berinteraksi dan menjawab beberapa hal.

Saat ditodong pertanyaan itu, akan memberikan jawaban yang ada di benak yang ditodong. Setelah berhasil berbicara pada satu sesi, biasanya akan terbiasa berani di sesi selanjutnya. Secara tak langsung, sudah belajar lebih percaya diri.

LDK juga akan lebih berani menyampaikan pendapat. Walau, setelah LDK tidak langsung berubah menjadi sosok yang vokal. Setidaknya, saat berada di lingkup kelompok kecil, akan berani mengungkapkan pendapat. Jadi, buat yang merasa sebagai pemalu, ada baiknya melatih kepercayaan diri kamu dengan mengikuti LDK.

\section{METODE PELAKSANAAN}

Kerangka pemecahan masalah merupakan serangkaian prosedur dan langkahlangkah dalam penelitian yang bertujuan untuk mendapatkan tahapan yang terstruktur 
secara sistematis, sehingga penelitian dapat dilakukan dengan efektif dan efisien. Kerangka pemecahan masalah atau tahapan dalam kegiatan ini adalah sebagai berikut:

Metode pelaksanaan program pengabdian kepada masyarakat sebagai berikut:

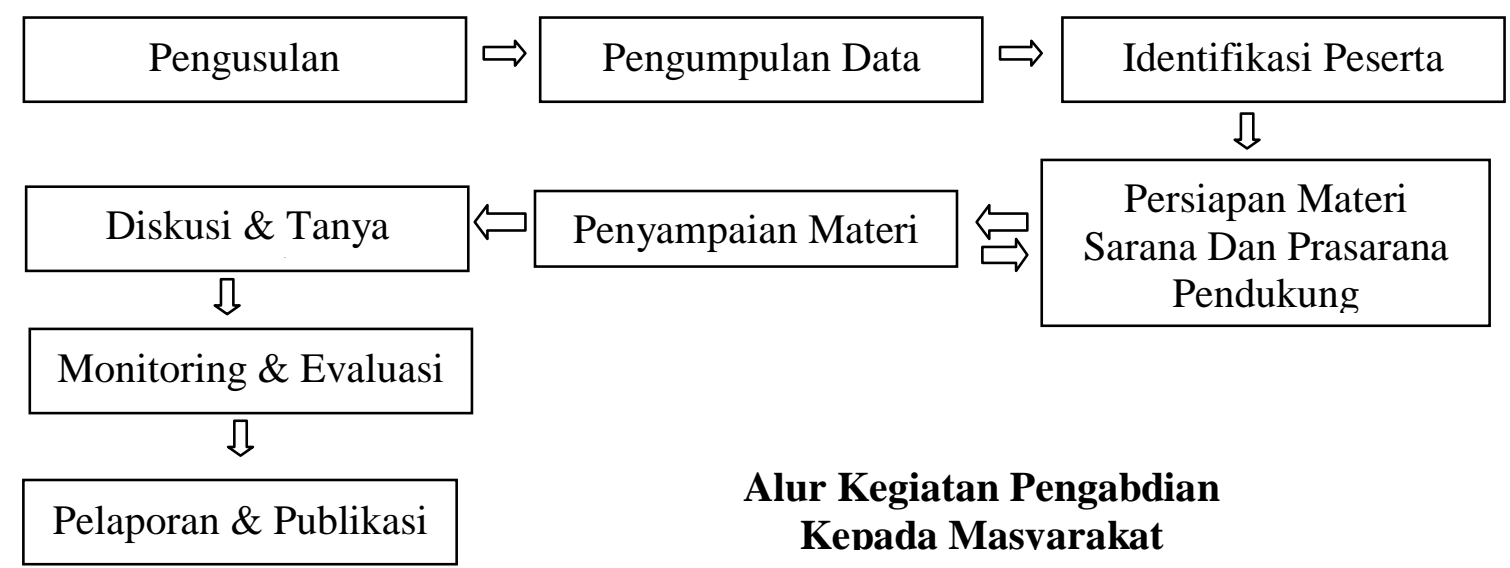

\section{HASIL DAN PEMBAHASAN}

\section{Secara garis besar Pelatihan Dasar Kepemimpinan}

1. Kedisiplinan

Kedisiplinan dibangun untuk membuat peserta paham terhadap norma dan etika yang ada. Apabila dapat memahaminya maka akan timbul tindakan yang sesuai. Dengan begitu seseorang dapat lebih sistematis dan teratur. Kedisiplinan juga memberikan pemahaman akan pentingnya nilai waktu yang membuat seseorang menghargai dan memanfaatkannya sebaik mungkin. Hal-hal tersebut akan menghasilkan ketentraman dan juga rasa saling percaya satu sama lain dalam organisasi.

\section{Rasa solidaritas}

Melalui kegiatan ini, seluruh peserta diuji rasa solidaritasnya. Bagaimana setiap individu harus rela berkorban demi kelompoknya, bagaimana mengenyampingkan ego, dan lainnya. Jika solidaritas terbentuk maka hubungan interpersonal pun akan terjadi dimana rasa kepedulian satu sama lain akan timbul, memahami kelebihan dan kekurangan, dan membantu disaat senang maupun duka. Dengan membangun solidaritas suatu kelompok akan menjadi kompak sehingga dapat mencapai tujuan dan keselarasan bersama.

\section{Bertanggung jawab}

Bertanggung jawab berarti menyelesaikan kewajiban yang seharusnya dilakukan. Dengan bertanggung jawab peserta membangun komitmen akan apa yang dikerjakan. Jika seseorang dapat memahaminya maka ia akan tau konsekuensi yang akan terjadi apabila kewajiban tidak dilaksanakan. Sikap 
I Nyoman Marayasa, dkk

bertanggung jawab sangat amat dibutuhkan dan merupakan hal yang penting dalam berorganisasi karena mempengaruhi kinerja secara keseluruhan.

\section{PENUTUP}

Pelaksanaan kegiatan pengabdian masyarakat oleh lembaga penelitian dan pengembangan masyarakat (LPPM) Universitas Pamulang yang dilakukan oleh dosendosen program studi Pendidikan Ekonomi dan Manajemen telah berjalan dengan lancar dan mendapat sambutan hangat dari tempat pelaksanaan kegiatan ini yaitu para anggota Pengurus Taman Belajar Kreatif Mekarsari.

Dengan ada kegiatan ini menjadikan para anggota Pengurus di lingkungan Taman Belajar Kreatif Mekarsari dapat memahami pentingnya pelatihan dasar kepemimpinan milenial

Selama kegiatan berlangsung peserta penyuluhan memberikan tanggapan yang sangat baik, hal ini dapat dilihat dari dukungan dan atusiasme mereka dalam setiap kegiatan yang diadakan.

Selain itu harapan kami dengan pengabdian ini dapat membuka wawasan dari para anggota Pengurus, sehingga tidak hanya memberikan tambahan pengetahuan tetapi juga dapat diterapkan khususnya dalam menerapkan kemampuan berorganisasi. Selain itu diharapkan juga dapat membantu dan meningkatkan kepemimpinan mereka dengan pendekatan terkini atau milenial.

\section{DAFTAR PUSTAKA}

Badu, S. Q., \& Djafri, N. (2017). Kepemimpinan dan Perilaku Organisasi. Kepemimpinan dan Perilaku Organisasi.

Edy Kumara, I., \& Utama, I. (2016). PENGARUH PELATIHAN TERHADAP KINERJA KARYAWAN DENGAN MEDIASI KEPEMIMPINAN PADA HOTEL SATRIYA COTTAGES KUTA BALI. None.

Samarenna, D., \& Siahaan, H. E. R. (2019). Memahami dan Menerapkan Prinsip

Kepemimpinan Orang Muda Menurut 1 Timotius 4:12 bagi Mahasiswa Teologi.

BIA': Jurnal Teologi Dan Pendidikan Kristen Kontekstual. https://doi.org/10.34307/b.v2i1.60

Siagian, S. P. (2003). Teori dan Praktek Kepemimpinan. Jakarta: Rineka Cipta.

Sri Wiranti, T. S. (2009). Model Kepemimpinan Dalam Organisasi. Jurnal STIE Semarang.

Sutikno, S. (2014). Pemimpin dan kepemimpinan. Pemimpin Dan Kepemimpinan. Tampi, B. J. (2014). Pengaruh Gaya Kepemimpinan dan Motivasi Terhadap Kinerja Karyawan Pada PT. Bank Negara Iindonesia, TBK (Regional Sales Manado). Jurnal “Acta Diurna” Volume III. No.4. 